Chaplinsky V. G. Educational ministry in the churches of the All-Ukrainian Union of Evangelical Baptist Churches of Ukraine

The Bible is the main source of the theological reflection of the Ukrainian Baptists and it directly influences their religious consciousness. The theology of the AUUA ECB* is conservative, traditionally oriented to the high, Bible-based, spiritual and moral standards. The personal pietism of the Evangelical Christians and Baptists implies the daily spiritual practice and compulsory observance of the biblical scriptures.

Today the need for Bible study makes itself felt. The Bible study is a missionary work. The performance of this work requires the education of the workers who will also conduct the Bible studies. It is imperative that people learn to individually read, investigate and analyze the Bible. To make it happen, the firm foundation must be laid, but it requires the long-term and continuous efforts. It is necessary to get closer to the people on making the personal efforts. The poor ones need help, the sick ones need the care, the ones being in mourning need the consolation, the unskilled need the instruction, the inexperienced need the advice. This is the way one can touch the hearts of the people and teach them the Word of God.

The formation of spiritual and moral effective leadership should be based on biblical foundations. The theology of leadership implies the comprehension of such fundamental concepts as faith, justice, love, etc. Therefore, people must follow Christian teachings. The books of the Bible provide a spiritual foundation for man regarding the main aspects of faith and life, including leadership. Believers often turned to the Bible to understand leadership and to guide leadership. The Baptist Church is an example of how a community of people can interact harmoniously to achieve a common goal.

Knowledge of God is the foundation in the formation of Christian leadership. Learning is not just transferring content from a mentor. This is a process of communication between people that involves issues of morality.

In order for the learning process to proceed without interference, the basic rules must be followed. This includes such moments as discipline in the classroom, justice, equal opportunities for students, etc. In addition, there are more personal problems that believers face and which may affect their spiritual growth. Christian teaching presupposes appropriate morality. Therefore, in this direction it is necessary to make conscious efforts to teach the principles of making the right decisions.

Key words: education, spirituality, church, Christian teaching, Baptism, leadership.

UDC 376

DOI https://doi.org/10.31392/NPU-nc.series5.2020.73-2.26

Czerw Monika, Karpuszenko Elena, Kukla Daniel

\title{
PEOPLE WITH DISABILITIES IN THE ACADEMIC EDUCATION AREA FROM PERSPECTIVE OF RESEARCH AND ANALYZES
}

Over the last two decades, there has been a gradual increase in the number of students with disabilities. This is facilitated by organizational, structural changes at the university, awareness and legal changes. At the same time, at the university level, teaching rules began to be applied, which determine the adaptation of the educational process to the needs of students with disabilities. It supports equal opportunities in access to education, multifaceted participation in public life and ensures personal development.

The article analyzes the state of university preparation for students with special needs. The data obtained as a result of the study show the changes taking place in the process of adapting education to the needs of people with disabilities, and therefore - leveling educational opportunities: removing architectural barriers (especially in universities that occupy old buildings), adaptation of curricula, formation of skills and competencies of teaching and administrative staff, the need to organize a first aid course and sign language course for employees, etc.

Employees' expectations regarding the learning opportunities of people with disabilities are considered, which also takes into account the difficulties and needs in implementing learning outcomes, the need to organize work according to the specifics of individual characteristics, including people with autism, and ways of student internships.

The study uses a method of analyzing existing sources, developed from reports from the State Fund for the Rehabilitation of Persons with Disabilities (PEFRON), the oversight of the High Audit Service (NIC) or the Ombudsman's Bulletin on Access to Academic Education for People with Disabilities. This made it possible to understand the situation with higher education on a national scale.

Key words: disability, higher education, adaptation, internship, employment, career.

(статтю подано мовою оригіналу)

Over the past two decades, there has been a gradual increase in the number of students with disabilities. This is facilitated by organisational, structural changes within the university, awareness and legal changes that have taken place in recent years. At the same time, study regulations (and not only) that determine the adaptation of the teaching process to the possibilities and needs of students with disabilities have become applicable at the university level. This supports equal opportunities in access to education, and thus multi-faceted participation in social life. It also ensures personal development and promotes independence.

The aim of the article is research people with disabilities in the academic education area from perspective of research and analyses. This publication uses the method of analyzing existing sources, developed from the reports of the State Fund for the Rehabilitation of the Disabled (PEFRON), the control of the Supreme Audit Office (NIK) or the Ombudsman Bulletin regarding the availability of academic education for people with disabilities. This enabled insight into the situation of higher education on a national scale. 
In addition, the authors of the publication carried out research regarding the issue raised in one of the public universities of the Silesian Voivodeship with the use of the diagnostic survey method. Students, lecturers and administrative staff participated in the research. The questionnaires used for the research were prepared for their needs (worksheet for university employees and version for students). 58 lecturers and 60 students participated in the research conducted at the turn of April and May 2019. Respondents could choose more than one answer to most of the questions asked.

Education of students with disabilities and the functioning of universities. Significant changes within higher education in Poland were visible in the 1990s. The current system of support for students with disabilities at many universities is already much more extensive, although much remains to be done. Universities successively introduce changes in the statute, study regulations or in the recruitment procedures which are beneficial for people who are not fully functional. They also develop appropriate strategies for students and / or employees with disabilities. Observable positive changes encourage people with disabilities to study. According to the latest NIK audit carried out in 2018 at 15 universities and on the basis of an anonymous survey of 597 disabled students and doctoral students, the number of students with disabilities in 2014-2017 remained at 2\% despite a general downward trend in this respect. In spite of a significant improvement in the situation, it should be emphasised that "the percentage of people with disabilities achieving higher education is still significantly lower compared to non-disabled people and in 2013 it was 9.1 to $25.8 \%$ " (Bulletin of the Ombudsman, 2015, No. 5).

Students with disabilities, just like the others, face many choices when deciding on further development of their educational careers. The decisions concern not only the choice of the university itself, the field of study, but also the mode of study.

Private schools are more accessible to students with disabilities. However, public universities as large units are better adapted to the needs of students with disabilities, they also often offer the support of an assistant to a disabled person, and probably due to the greater number of students with disabilities, the degree of activity (scope of assistance) for them is more advanced (Moroń, 2014).

Adaptation of many universities to the needs of people with disabilities is often possible thanks to the subsidies awarded by the Ministry of Science and Higher Education. It is surprising that as many as 13 out of 15 universities audited by the Supreme Audit Office did not use the funds received in full. In the years 2015-2017, the subsidy amounted to PLN 17.5 million, of which universities spent on average about 50\% (ibid). Universities in $32 \%$ allocated the received subsidy to the salaries of assistants of persons with disabilities and sign language interpreters. The same amount of subsidy was allocated to the salaries of university employees supporting people with disabilities. The third category of expenses $(25 \%)$ was the so-called other expenses, including the purchase of rehabilitation equipment. Only $9 \%$ of the funds received were allocated to the purchase of equipment and teaching aids for students and doctoral students with disabilities, and $2 \%$ was spent on training university staff. The use of subsidies is puzzling, especially since modern technology allows the use of electronic devices, e.g. video translator, which allows you to connect in real time with a sign language interpreter, which would limit the scale of expenses in this scope.

A student with a disability has the option of applying for institutional support. A necessary condition is the presentation of a disability certificate. In many cases, where the disability is not visible, the disability certificate is not disclosed. This has different consequences. There may be various problems with mastering specific learning content at a certain pace. The lack of such information also closes the way to apply for a special scholarship for people with disabilities. Disclosure of disorders may also lead to the exclusion of the individual from the student community. Of course, this situation should not be treated as a rule. A clear and honest explanation of your situation often favours acceptance and symmetrical relationships. The creation of seemingly beneficial mechanisms facilitating favours discrimination while limiting the possibility of integration (Gajdzica, 2015). The report assessing the availability of academic education for people with disabilities, requested by the Ombudsman, emphasises that two-thirds of the students participating in the study believe that students with disabilities should be set to the same requirements as for fully-functioning students (Bulletin of the Ombudsman, 2015).

There is no doubt that people with disabilities should receive additional support. In 1997, a special scholarship was introduced for people with disabilities. Unfortunately, it did not cover all interested parties. This form of assistance was only available to people studying full-time at public universities. Changes regarding the granting of the scholarship were introduced only in 2005, where all students of universities could benefit from this form of assistance. In addition, receiving a scholarship for people with disabilities does not preclude the use of other forms of financial support, e.g. a social scholarship (Moroń, 2014).

According to the above-mentioned NIK report, all the audited universities provided disabled students with didactic support. It referred to such activities as: the possibility of implementing an individual course of study, the possibility of using the assistance of faculty supervisors and assistants of persons with disabilities. In addition, libraries and teaching rooms were adapted to the needs and capabilities of students who are not fully functional (NIK. Information on the results of the audit, 2018).

It is worth noting that the university's duty is to provide support to people with disabilities at the recruitment stage. At this stage, the smoothly running recruitment process should be treated as the first step on the path to higher education, which in the future will support the possibilities of using the potential of people with disabilities. This 
brings huge benefits. Higher education intensifies the possibility of getting a job, although it is not a determining factor. The analysis of employment rates based on economic activity research (BAEL) proves that students with disabilities holding a university diploma are more willingly employed (27\%) compared to people with disabilities in secondary education (14.1\%). It is worrying that about $70 \%$ of people with disabilities with higher education do not take up employment (see Study on the impact of the direction and level of education on the professional activity of people with disabilities. Part 1, 2009; AI Brzezińska, R. Kaczan et al., 2008).

The successive elimination of architectural barriers at universities is also a response to the needs of disabled students. Unfortunately, in Poland, knowledge about the so-called universal design is still a niche. Solutions implemented by individual universities do not always meet the expectations of their addressees.

Preparation of universities for education of students with disabilities - analysis of own research results

The information obtained shows that the number of employees and students not fully functional associated with the university constitutes a total of about 100 people, out of 669 employees (including 100 people in administrative positions) and about 4.5 thousand of all students (according to data sent to the Central Statistical Office. As of April 30, 2019). Unfortunately, obtaining more detailed data, i.e. a specific number of students with disabilities or types of disabilities among students and employees proved to be impossible. The indicated number of about 100 people with different types of disabilities is a relatively small percentage compared to e.g. the University of Wrocław, where the number of students with various disabilities in 2015 was 1000 (Sztobryn-Giercuszkiewicz, 2016). It should be emphasized that these data in both cases do not reflect the actual number of students and / or university employees with disabilities. As already mentioned in the first part of this article, these figures are understated. They cover only those units which have disclosed their disability certificate.

According to research, surveyed students derive information on adapting the university to the needs of people with disabilities primarily from websites (33.4\%). The result is not surprising considering the fact, that online data collection is a convenient and a fast way. In addition, the websites of universities may suggest the scope and / or degree of involvement in the process of adaptation to the needs of people with disabilities. Unfortunately, the website of this university still needs refinement, although the option of using contrast or enlarging text has already been introduced.

At the same time, the information that $88.5 \%$ of the surveyed students did not encounter difficulties in relation to people with disabilities during recruitment may on the one hand suggest that there are no actual impediments, on the other that the students themselves or their friends have not encountered such a situation. It can also be assumed that this is the result of a relatively small number of candidates with disabilities for studies. It also seems that the respondents are not aware of the real needs and difficulties encountered in the daily functioning of this group of people. As an example of a lack of reflection, one can mention the many architectural barriers. For $43.4 \%$ of the surveyed students in the university buildings, where the research was carried out, architectural barriers do not exist, which contradicts the real state, what has already been mentioned. For the remainder of the respondents, architectural barriers (11.6\%) were the obstacles at the recruitment stage. Then, respectively $6.6 \%$ of respondents indicated the lack of properly adapted documents and not adjusted websites. The attitude of the recruitment commission to a person with a disability is a factor hindering the recruitment process for $5.0 \%$ of respondents, and difficulties in Internet access for $1.67 \%$ of surveyed students.

In turn, in the opinion of university employees, the main factor hindering the recruitment of people with disabilities to the university is the lack of a sign language interpreter, which was the answer chosen by $62.9 \%$ of respondents and architectural barriers (54.4\%). Subsequently, for 27.2\% of respondents there are restrictions resulting from the lack of appropriately adapted documents, unadjusted websites $(22.1 \%)$, the ratio of people on the recruitment commission to people with disabilities $(10.2 \%)$ and difficulties in accessing the Internet (5.1\%).

Analysing the aspect of barriers in access to universities, it is worth emphasizing that in the opinion of both surveyed groups (with slight differences) these are primarily financial restrictions, architectural barriers and distance from home. The largest percentage of responses selected $(61.2 \%)$ among the teaching and administrative staff were the architectural barriers (this response was chosen by $41.7 \%$ of the surveyed students). However, among students the most frequently chosen answer (46.7\%) were financial constraints. At the same time, $52.7 \%$ of university employees indicated this group of difficulties. Distance from home is a barrier to access to universities in Poland for $56.1 \%$ of the staff working at the university and $45 \%$ of the surveyed students. It is worth noting that for $34 \%$ of the surveyed employees, an important barrier is the ignorance of the staff about disability. Restrictions in this area are noticed by $13.3 \%$ of students. The other categories related to housing difficulties (this response was chosen by $28.9 \%$ of staff and $26.7 \%$ of students) and medical care (just over $13 \%$ in both groups). In addition, the surveyed students indicated the attitude of lecturers (16.7\%). Only 3.4\% of university employees believe that the attitude of lecturers constitutes a barrier to access to higher education. It is worth noting that no employee indicated restrictions resulting from the attitude of administrative employees. In turn, for $15 \%$ of students there are such restrictions.

The respondents were also asked about the forms of support offered by the university to people with disabilities. In both examined groups, eliminating architectural barriers was considered the most important. $70.1 \%$ of students participating in the survey and $69.7 \%$ of employees surveyed paid attention to this. The need to adapt the dormitories was indicated by $54.4 \%$ of the teaching and academic staff and $41.7 \%$ of students. For $43.4 \%$ of students, it was 
important to adapt the study conditions to the capabilities and needs of people with disabilities. $39.1 \%$ of university employees drew attention to this aspect. Financial support is a form of assistance indicated by $42.5 \%$ of the surveyed staff and administrative employees and $40 \%$ of the surveyed students. The employees participating in the survey mentioned: the help of assistant (37.4\%), assistance related to transport $(35.7 \%)$, the possibility of using a sign interpreter and access to specialised equipment and devices, where both categories were selected by $32.3 \%$ study participants. In addition, $22.1 \%$ of respondents indicated the need to adapt documents and other materials, $15.3 \%$ appropriate university markings (e.g. information boards in Braille alphabet), 13.6\% adaptation of the library, and $8.5 \%$ help psychologists. In turn, surveyed students $(36.7 \%)$ pointed to the need to support from an assistant. $33.4 \%$ of students pointed to the need for transport-related assistance and access to specialized equipment and devices. Then the respondents chose: appropriate university marking $(25 \%)$, the possibility of using a sign language interpreter $(23.3 \%)$. In turn, $10 \%$ of respondents chose the need to adapt documents and other materials, and to adapt the library to the needs of students with disabilities. Similarly, to the group of surveyed university employees, psychological assistance was the category most rarely chosen by students. It was selected only by $8.3 \%$ of respondents. It is interesting that neither university employees nor students pay attention to the need to adapt the study program to the specific needs of people with disabilities.

Referring to the above-mentioned financial support, it is worth emphasizing that, according to both groups of respondents, it should refer primarily to a social scholarship and covering travel costs. The need for such assistance in the first case was indicated by $68 \%$ of university employees and $66.8 \%$ of surveyed students. $30.6 \%$ of the administrative and teaching staff and $26.7 \%$ of students indicated assistance in covering travel costs. In turn, $32.3 \%$ of employees and $23.3 \%$ of students chose the category "the opportunity to rent specialized equipment". Interesting is the fact that $22.1 \%$ of the staff and only $1.67 \%$ of the studying people paid attention to co-financing for the purchase of rehabilitation equipment. For $6.8 \%$ of employees surveyed and $8.3 \%$ of students, the possibility of obtaining additional financial support should be the same as for other students.

Summarising previous analyses among the three most frequently chosen categories of responses indicated by both groups of respondents, eliminating architectural barriers should primarily include: adaptation of toilets, which was important for $74.8 \%$ of employees surveyed and $43.4 \%$ of students, removal of thresholds or the use of ramps (for this slightly less, because $71.4 \%$ of administrative and teaching staff and $56.7 \%$ of surveyed students) drew attention to the problem and the adaptation of lecture halls, where in both groups of respondents about $43 \%$ of respondents indicated the need for change in this respect. Architectural barriers remain a problem for many universities in Poland. In addition to eliminating architectural barriers and institutional support, the teaching support provided to students with disabilities is very important. And so, in the opinion of university employees, adapting the study conditions to the capabilities and needs of people with disabilities should primarily concern the possibility of changing the form of credit / exam from oral to written and vice versa (59.5\%). Then the following were selected: the option of recording lectures $(45.9 \%)$, out-of-order service $(44.2 \%)$, extending the duration of the exam / colloquium or the possibility of using specialized equipment. $39.1 \%$ of respondents indicated this need in both cases. Subsequently, they were: assistance in recruitment $(32.3 \%)$, creation of an ICT room equipped with specialized equipment (28.9\%), access to PE classes with elements of rehabilitation $(25.5 \%)$, creation of a library of digital books $(23,8 \%)$, the creation of specialized equipment rental $(17 \%)$. The adaptation of the university's websites was indicated by $13.6 \%$ of the respondents, and $8.5 \%$ were chosen by the introduction of longer breaks from the study participants.

On the other hand, in the opinion of the surveyed students, adjusting the study conditions should include, above all, out of turn services. This answer was given by $46.7 \%$ of respondents. The length of the exam / colloquium was extended by $38.4 \%$ of respondents. Then, in turn, $36.7 \%$ of respondents chose the option of using specialized equipment and the opportunity to record lectures. Assistance in recruitment was important for 35\% of respondents, and the possibility of changing the form of credit for $31.7 \%$. The respondents also pointed to: providing access to PE classes with elements of rehabilitation (30\%), creating a library of digital books (28.3\%), creating a specialist equipment rental (18.3\%) and an ICT room equipped with specialized equipment (13.3\%). 11.6\% of respondents chose to adjust university websites and provide longer breaks.

In addition, even though, as it turned out in both study groups, the need to create specialized equipment rentals was not recognized as one of the most important, the surveyed students were asked about the type of equipment that should be for rental. Laptops with specialized software was the most frequently chosen category. Such an opinion was expressed by almost $52 \%$ of respondents. $48.4 \%$ of respondents pointed to Braille notebooks, $33.4 \%$ for specialized keyboards, 20\% voice recorders and 3.3\% trackballs.

Both groups of respondents considered that adapting documents and other materials to the needs of students who are not fully functional should include, first of all, enabling the use of software translating text into speech and vice versa $(69.7 \%$ of staff and $48.4 \%$ of students). Next, in the opinion of the teaching and administrative staff, the university should provide access to a sign language interpreter (42.5\%), texts written in Braille alphabet (37.4\%), the possibility of enlargement (34\%) and larger print (32.3\%). On the other hand, for $40 \%$ of the surveyed students it was important to translate the texts into Braille, and then $33.4 \%$ successively: the possibility of enlarging and access to a sign language interpreter. In the last place, the surveyed students, like the staff working at the university, chose larger print (26.7). 
The respondents were also asked about the attitude of students to people with disabilities. The distribution of answers selected in both groups of respondents was similar. Both the surveyed employees and students indicated that the attitude is good. Students are happy to help. In both groups, this response was indicated by over $50 \%$ of respondents. $40 \%$ of surveyed students and $30 \%$ of university employees rate this ratio very well. The answer "wrong, not willing to help" was given by slightly over $3 \%$ of respondents in both groups. No student pointed to ignorance and a very bad attitude of students towards people with disabilities. However, this opinion was expressed by $3.4 \%$ of the university employees surveyed. At the same time, $8.5 \%$ of the teaching and administrative staff have no opinion on this subject, nor does $5 \%$ of students.

At the same time, it is worth adding that the vast majority of both university employees (85\%) and students $(80 \%)$ have never witnessed an improper treatment of a person with disabilities. This situation was observed by $10 \%$ of the surveyed students, where in the first case it referred to the mistreatment of a disabled person by the employees, and in the second case by other students. None of the university staff observed that this was the case of other students. However, $13.6 \%$ of respondents indicated that this was the case on the part of other university employees.

Elimination of such situations may be facilitated by undertaking integration activities, although, interestingly, slightly more than $5 \%$ of the surveyed university employees do not feel such a need. No student gave such an answer. However, in the overwhelming opinion of both groups of respondents (over 40\%), such activities should be undertaken at least once a semester. For $25 \%$ of the surveyed students and $17 \%$ of the teaching and academic staff, integration activities should be undertaken at least once a year. Twice a semester, slightly more than $18 \%$ of surveyed students and less than $12 \%$ of university employees indicated. Over $20 \%$ of university employees and $15 \%$ of students participating in the survey showed no opinion on this subject.

Both groups of respondents pointed out that both students and employees at the university should, first of all, organise training to raise awareness related to the presence of people with disabilities within its walls. Approximately $50 \%$ of the surveyed students and $52 \%$ of employees participating in the survey expressed this need. Subsequently, teaching and administrative staff indicated training enabling spatial orientation at the university for students with disabilities (37.4\%), a first aid course (34\%) and a sign language course for employees (just over 22\%). Among students, about $33 \%$ of respondents believe that it is necessary to organise a first aid course and a sign language course for employees. According to less than $17 \%$ of respondents, training should be organised to facilitate spatial orientation at the university for the students with disabilities.

In addition, university employees were asked about the possibility of finding work by students with disabilities in their profession after graduation. Almost 58\% of the respondents gave an affirmative answer, however, indicating that it will require a lot of effort and time. In turn, around $16 \%$ of respondents say that this will be associated with many problems. Only $8.5 \%$ of respondents believe that a student with a disability will not have problems finding a job adequate to their education. About 5\% of survey participants indicate that graduates with disabilities will not work in their profession, and $12 \%$ of respondents did not think about it.

\section{Conclusion}

The study presents an outline of the analysis of the state of university preparation for education of people with various disabilities. Data obtained from the analysis of reports and research reports show the changes taking place in the process of adapting education to the needs of people with disabilities and thus equalizing educational opportunities.

It should be noted that the above text is only an outline of the needs or activities undertaken. The university took steps in order to adapt broadly understood conditions to studying people with disabilities. It seems, however, that this is just the beginning. It is necessary to take several actions related to the elimination of architectural barriers (especially at universities occupying old buildings), and above all related to the adaptation of the education program. And it's not about adjusting the form of passing or extending the time to write an exam. Attention should be paid primarily to the implementation of learning outcomes by students with disabilities. In the case of the studied university, one should consider the reasons for the very small number of students with disabilities studying within its premises.

\section{Bibliography:}

1. Badanie wpływu kierunku i poziomu wykształcenia na aktywność zawodową osób niepełnosprawnych. Raport końcowy. Część 1 z 6. PEFRON, rok 2009, p. 16.

2. Basta, J., 2016. Studenci z niepełnosprawnością w percepcji pełnosprawnych rówieśników. In: Szczupał, B., Kutek-Sładek, K., 2016. Wielowymiarowość integracji społeczno-zawodowej studentów z niepetnosprawnościa, Wyd. UPJPII, Kraków 2016, p. 192. ISBN 978-83-7438-506-0.

3. Brzezińska, A. I., Kacza, R., Piotrowski, K., Rycielski, P., 2008. Uwarunkowania aktywności zawodowej osób z ograniczeniami sprawności: kapitał osobisty i społeczny. In: Nauka, 2008, No. 2, p. 146. ISSN 1231-8515.

4. Gajdzica, Z., 2015. Student z niepełnosprawnością w przestrzeni szkoły wyższej - pomiędzy pedagogiką długu a pedagogiką wspólnotowości. In: Rocznik Lubuski, Vol. 41, 2015, part 2, pp. 221, 223-224, 227. ISSN 0485-3083

5. Konwencja o prawach osób niepełnosprawnych z dnia 13 grudnia 2006r., Dz. U. 2012, poz. 1169.

6. Moroń, D., 2014. Studenci niepełnosprawni na publicznych i niepublicznych uczelniach wyższych. In: Wrocławskie Studia Politologiczne, 2014, No 16, pp. 238, 242, 244. ISSN 1643-0328.

7. NIK. Informacja o wynikach kontroli: Realizacja przez uczelnie akademickie i zawodowe obowiązku stworzenia niepełnosprawnym studentom i doktorantom warunków do pełnego udziału w procesie kształcenia i w badaniach naukowych, nr ew. 78/2018/P/18/087/LOL, pp. 5-7, 10-11, 14-15, 17-18, 22-24. 
8. Rozporządzenie Ministra Nauki i Szkolnictwa Wyższego z dnia 25 września 2014 r., Dz. U. 2014, poz. 1302.

9. Sztobryn-Giercuszkiewicz, J., 2016. Alter idem - student z niepełnosprawnością w systemie szkolnictwa wyższego. In: Zakrzewska-Manterys, E., Niedbalski, J., 2016. Samodzielni, zaradni, niezależni. Ludzie niepetnosprawni w systemie polityki, pracy $i$ edukacji, Wyd. Uniwersytetu Łódzkiego, Łódź 2016, pp. 102-104, 113-114, 118. ISBN 978-83-8088-074-0.

10. Ustawa Prawo o szkolnictwie wyższym z dnia 27 lipca 2005r., Dz. U. 2012, poz. 572 ze zm.).

11. Ustawa Prawo o Szkolnictwie wyższym z dnia 20 lipca 2018 r., Dz. U. 2018, poz. 1668.

12. Zasada równego traktowania - prawo i praktyka, nr 16. Dostępność edukacji akademickiej dla osób z niepełnosprawnościami, "Biuletyn Rzecznika Praw Obywatelskich" 2015, nr 5, pp. 6, 14, 16-17, 32.

\section{References:}

1. Badanie wpływu kierunku i poziomu wykształcenia na aktywność zawodową osób niepełnosprawnych. Raport końcowy. [Examination of the impact of the direction and level of education on the professional activity of the disabled. Final report.] Część 1 z 6. PEFRON, 2009, p. 16. [in Poland].

2. Basta, J., 2016. Studenci z niepełnosprawnością w percepcji pełnosprawnych rówieśników. [Students with disabilities in the perception of able-bodied peers.] In: Szczupał, B., Kutek-Sładek, K., 2016. Wielowymiarowość integracji społeczno-zawodowej studentów z niepetnosprawnościa, [Multidimensionality of socio-professional integration of students with disabilities] Wyd. UPJPII, Kraków 2016, p. 192. ISBN 978-83-7438-506-0. [in Poland].

3. Brzezińska, A. I., Kacza, R., Piotrowski, K., Rycielski, P., 2008. Uwarunkowania aktywności zawodowej osób z ograniczeniami sprawności: kapitał osobisty i społeczny. [Determinants of professional activity of people with disabilities: personal and social capital.] In: Nauka, 2008, No. 2, p. 146. ISSN 1231-8515. [in Poland].

4. Gajdzica, Z., 2015. Student z niepełnosprawnością w przestrzeni szkoły wyższej - pomiędzy pedagogiką długu a pedagogiką wspólnotowości. [A student with a disability in the space of a university - between debt pedagogy and community pedagogy.] In: Rocznik Lubuski, Vol. 41, 2015, part 2, pp. 221, 223-224, 227. ISSN 0485-3083 [in Poland].

5. Konwencja o prawach osób niepełnosprawnych z dnia 13 grudnia [Convention on the Rights of Persons with Disabilities of 13 December ] 2006r., Dz. U. 2012, poz. 1169. [in Poland].

6. Moroń, D., 2014. Studenci niepełnosprawni na publicznych i niepublicznych uczelniach wyższych. [Students with disabilities at public and private universities.] In: Wrocławskie Studia Politologiczne, 2014, No 16, pp. 238, 242, 244. ISSN 1643-0328. [in Poland].

7. NIK. Informacja o wynikach kontroli: Realizacja przez uczelnie akademickie i zawodowe obowiązku stworzenia niepełnosprawnym studentom i doktorantom warunków do pełnego udziału w procesie kształcenia i w badaniach naukowych, [7. The SCC. Information on the results of the control: Implementation by academic and vocational universities of the obligation to create conditions for disabled students and doctoral students to fully participate in the education process and research] $\mathrm{nr}$ ew. 78/2018/P/18/087/LOL, pp. 5-7, 10-11, 14-15, 17-18, 22-24. [in Poland].

8. Rozporządzenie Ministra Nauki i Szkolnictwa Wyższego z dnia 25 września 2014 r. [8. Regulation of the Minister of Science and Higher Education of 25 September 2014] , Dz. U. 2014, poz. 1302. [in Poland].

9. Sztobryn-Giercuszkiewicz, J., 2016. Alter idem - student z niepełnosprawnością w systemie szkolnictwa wyższego [Alter idem - a student with a disability in the higher education system]. In: Zakrzewska-Manterys, E., Niedbalski, J., 2016. Samodzielni, zaradni, niezależni. Ludzie niepetnosprawni w systemie polityki, pracy i edukacji [Independent, resourceful, independent. People with disabilities in the system of politics, work and education] Wyd. Uniwersytetu Łódzkiego, Łódź 2016, pp. 102-104, 113-114, 118. ISBN 978-83-8088-074-0. [in Poland].

10. Ustawa Prawo o szkolnictwie wyższym z dnia 27 lipca 2005r. [The Law on Higher Education of 27 July 2005], Dz. U. 2012 , poz. 572 ze zm.). [in Poland].

11. Ustawa Prawo o Szkolnictwie wyższym z dnia 20 lipca 2018 r. [The Act on Higher Education of 20 July 2018], Dz. U. 2018 , poz. 1668. [in Poland].

12. Zasada równego traktowania - prawo i praktyka, nr 16. Dostępność edukacji akademickiej dla osób z niepełnosprawnościami [12. The principle of equal treatment - law and practice, No. 16. Accessibility of academic education for people with disabilities,], "Biuletyn Rzecznika Praw Obywatelskich" 2015, nr 5, pp. 6, 14, 16-17, 32. [in Poland].

\section{Черв Моніка, Карпушенко Елена, Кукла Даніель. Люди з обмеженими можливостями в галузі академічної освіти з точки зору досліджень та аналізів}

За останні два десятиліття спостерігається поступове збільшення кількості студентів з обмеженими можливостями. Цьому сприяють організаційні, структурні зміни в університеті, обізнаність та правові зміни. Водночас на рівні університету стали застосовуватися правила навчання, які визначають адаптацію навчального проиесу до потреб студентів-інвалідів. Це підтримує рівні можливості в доступі до освіти, багатогранну участь у суспільному житті і забезпечує особистісний розвиток.

У статті проаналізовано стан університетської підготовки до навчання студентів з особливими потребами. Дані, отримані в результаті дослідження, свідчать про зміни, щзо відбуваються в процесі адаптації освіти до потреб людей з обмеженими можливостями, а саме: усунення архітектурних бар'єрів (особливо в університетах, що займають старі будівлі), адаптацію навчальних програм, формування навичок та компетенцій викладацького та адміністративного персоналу, необхідність організації для працівників курсу першої допомоги та курсу жестової мови тощо.

Розглянуто очікування працівників щзодо можливостей навчання людей з обмеженими можливостями, що водночас передбачає врахування труднощів і потреб у впровадженні результатів навчання, необхідність організації роботи відповідно до специфіки індивідуальних особливостей, у тому числі людей зі спектром аутизму, а також способи здійснення стажувань студентів.

У дослідженні використовується метод аналізу існуючих джерел, розроблений із звітів Державного фонду реабілітаиії інвалідів (PEFRON), контролю Вищої аудиторської служби (НIК) або Бюлетеня омбудсмена щцодо доступності академічної освіти для людей з інвалідністю. Це дало змогу зрозуміти ситуацію з вищою освітою в національному масштабі.

Ключові слова: інвалідність, вища освіта, адаптація, стажування, працевлаштування, кар'єра. 